\title{
Peering into Avian Influenza A(H5N8) for a Framework towards Pandemic Preparedness
}

\author{
Joshua Yi Yeo ${ }^{1, *(D)}$ and Samuel Ken-En Gan ${ }^{1,2}$ (D) \\ 1 Antibody \& Product Development Lab, EDDC-BII, Agency for Science, Technology and Research (A*STAR), \\ Singapore 138672, Singapore; samgan@apdskeg.com \\ 2 APD SKEG Pte Ltd., Singapore 439444, Singapore \\ * Correspondence: joshua_yeo@eddc.a-star.edu.sg; Tel.: +65-6407-0584
}

check for updates

Citation: Yeo, J.Y.; Gan, S.K.-E. Peering into Avian Influenza A(H5N8) for a Framework towards Pandemic Preparedness. Viruses 2021, 13, 2276. https://doi.org/10.3390/ v13112276

Academic Editors: Mariana Baz and Edin Mifsud

Received: 27 September 2021

Accepted: 12 November 2021

Published: 15 November 2021

Publisher's Note: MDPI stays neutral with regard to jurisdictional claims in published maps and institutional affiliations.

Copyright: (c) 2021 by the authors. Licensee MDPI, Basel, Switzerland. This article is an open access article distributed under the terms and conditions of the Creative Commons Attribution (CC BY) license (https:/ / creativecommons.org/licenses/by/ $4.0 /)$.
Abstract: 2014 marked the first emergence of avian influenza A(H5N8) in Jeonbuk Province, South Korea, which then quickly spread worldwide. In the midst of the 2020-2021 H5N8 outbreak, it spread to domestic poultry and wild waterfowl shorebirds, leading to the first human infection in Astrakhan Oblast, Russia. Despite being clinically asymptomatic and without direct human-tohuman transmission, the World Health Organization stressed the need for continued risk assessment given the nature of Influenza to reassort and generate novel strains. Given its promiscuity and easy cross to humans, the urgency to understand the mechanisms of possible species jumping to avert disastrous pandemics is increasing. Addressing the epidemiology of H5N8, its mechanisms of species jumping and its implications, mutational and reassortment libraries can potentially be built, allowing them to be tested on various models complemented with deep-sequencing and automation. With knowledge on mutational patterns, cellular pathways, drug resistance mechanisms and effects of host proteins, we can be better prepared against H5N8 and other influenza A viruses.

Keywords: H5N8; influenza; virus; antiviral; mutation; reassortment; therapeutics; vaccines

\section{Influenza A Viruses and Its Subtypes}

Among the four influenza viruses (A, B, C and D), Influenza A viruses (IAVs) and Influenza B viruses (IBVs) have the potential to cause pandemics [1]. IAVs are divided into subtypes based on their viral surface glycoproteins: hemagglutinin (HA, subtypes H1 to H18) and neuraminidase (NA, subtypes N1 to N11). The Influenza A virion, studded with HA and NA, contains the viral genome that encodes for its proteins (see Figure 1A, [2]). The surface antigen, HA, binds to the terminal sialic acids of glycoprotein and glycolipids on host cells for viral entry, while NA cleaves the sialic acids to release the virions $[3,4]$. Given the importance of these viral proteins, their functions and the life-cycle of IAVs are extensively studied and reviewed [5-8].

IAVs are known to infect a broad range of hosts including humans, swine, domestic poultry, waterfowl shorebirds, equine, sea mammals and bats (see Figure 1B, [6,9]). The influenza A (H1N1) pdm09 virus that brought about the $2009 \mathrm{H} 1 \mathrm{~N} 1$ pandemic resulted in the loss of an estimated 151,700 to 575,400 lives worldwide during its first year of circulation [10]. More recently, the first H5N8 human infection was reported in Russia on 18 February 2021 [11], reigniting interest on its transmission to humans and highlighting the importance of preparedness against H5N8 and similar influenza A viruses. 
(A)

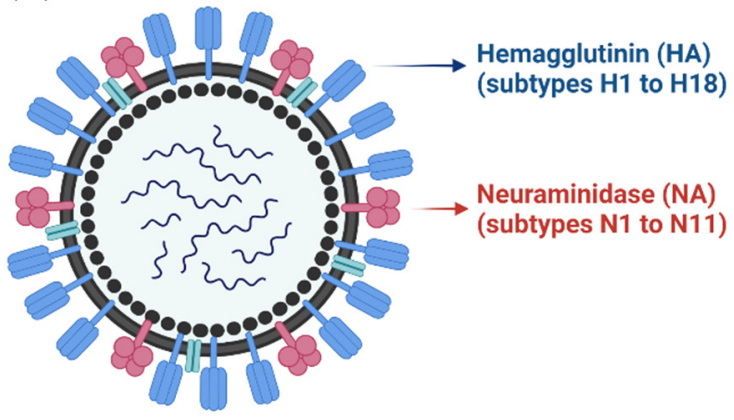

\begin{tabular}{|l|l|}
\hline Protein & Abbreviation \\
\hline Polymerase basic protein 2 & PB2 \\
\hline Polymerase basic protein 1 & PB1 \\
\hline Polymerase acidic protein & PA \\
\hline Hemagglutinin & HA \\
\hline Nucleoprotein & NP \\
\hline Neuraminidase & NA \\
\hline Matrix & M \\
\hline Non-structural protein & NS \\
\hline
\end{tabular}

(B)

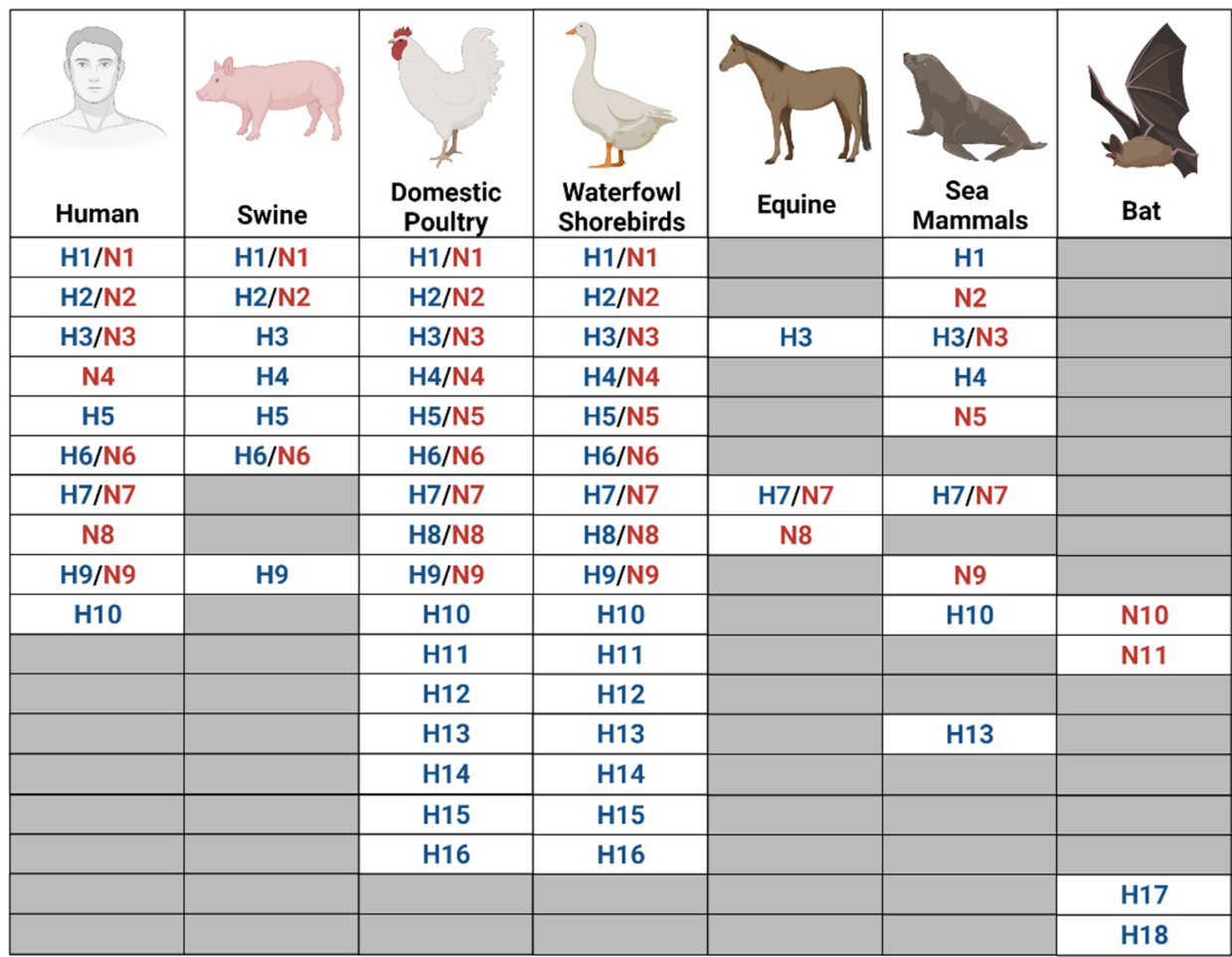

Figure 1. Influenza A viruses. (A) Structure of Influenza A viruses. (B) Hosts of Influenza A and their subtypes. Adapted from Mostafa et al. [6] and created with BioRender.com.

\section{Epidemiology of $\mathrm{H} 5 \mathrm{~N} 8$}

Named according to its HA 5 and NA 8 proteins, H5N8 first emerged on a farm in Jeonbuk Province, South Korea [12]. It was classified as a highly pathogenic avian influenza (HPAI) with an intravenous pathogenicity index (IVPI, the mean score per bird per observation over the 10-day period, ranging from 0 which indicates that no birds displayed clinical signs, to 3 which indicates the death of all birds [13]) of $>1.2$, the equivalence of $\geq 75 \%$ mortality [14]. First emerging in 2014, it spread throughout Asia, Europe, and the United States, infecting poultry and threatening public health, with this first wave subsiding in 2015. Attempts to control its spread led to the culling of more than 48 million poultry birds (the vast majority being chickens of which 38.4 million are egg-laying hens and 7.8 million turkeys) resulting in a loss of $\sim$ US $\$ 3.3$ billion in the poultry industry [15] and further affecting food production.

Fueled by the outbreak, myriads of viral sequences were deposited on the GISAID platform and catalyzed the initiation of The Global Consortium for H5N8 and Related Influenza Viruses [16,17]. One particular epidemiological study [17] brought into focus the vital role of long-distance migratory birds in the global spread of avian influenza viruses. 
The hemagglutinin (of clade 2.3.4.4) was also found to be remarkably promiscuous, capable of generating reassortants of multiple H5Nx IAVs of varying neuraminidase subtypes.

Shadowed by the COVID-19 pandemic, the recent 2020-2021 H5N8 outbreak affected both poultry and wild birds worldwide, particularly in Bulgaria, Czech Republic, Egypt, Germany, Hungary, Iraq, Japan, Kazakhstan, Netherlands, Poland, Romania, United Kingdom, and Russia [11]. In Astrakhan Oblast, Russia, an outbreak of clade 2.3.4.4b H5N8 caused the deaths of $11.2 \%$ of egg laying hens and the first $\mathrm{H} 5 \mathrm{~N} 8$ human transmissions to seven poultry farm workers and personnel (five females and two males of ages from 29 to 60 years old) on 18 February 2021 [11]. Despite being clinically asymptomatic with no transmission to close contacts, serological tests suggested recent infections.

Through investigations using Madin-Darby Canine Kidney (MDCK) cells in a focus reduction neutralization assay (FRNA), four of the seven poultry workers who were PCRpositive had detectable FRNA titers in their initial serum samples [18]. Seroconversion was detected in their second serum samples fourteen days later, with one having a four-fold increase and another two having a two-fold increase in FRNA titer compared to their first serum sample. Their third serum sample, tested 44 days later, revealed a decrease in FRNA titers compared to their second serum samples. In the second and third serum samples, the maximum hemagglutination inhibition assay (HIA) titer observed was 1:20, and not indicative of zoonotic influenza infection. Using biolayer interferometry (BLI), specific IgG antibodies against influenza A/Astrakhan/3212/2020(H5N8) were detected for the five serum samples on the 14th day and for all samples on the 44th day.

While there was no evidence of human-to-human transmission of A/Astrakhan/3212/ 2020(H5N8) and its extended clade 2.3.4.4. viruses [19], the World Health Organization (WHO) continues to stress the importance of global surveillance and the need for continued risk assessment [11] to avert disastrous pandemics [20].

\section{Understanding Transmission and Species Jumping}

\subsection{In Vitro, In Vivo and Ex Vivo H5N8 Models}

To better illustrate the propensity of H5N8 to species jump, the potential of cross-species infection of H5Nx viruses have been extensively studied (summarized in Table 1). Evaluating the transmission and virulence of A/northern pintail/Washington/40964/2014(H5N2), A/gyrfalcon/Washington/41088-6/2014 (H5N8) and A/Thailand/16/2004(H5N1) [21], H5N2 and H5N8 were found to cause severe disease in high titers in mice. Similarly, in infected ferrets, efficient replication in the upper and lower respiratory tracts were associated with only mild clinical symptoms with no evidence of systemic infection. In fact, H5N8 could not be transmitted between ferrets through direct contact. Assessing viral replication kinetics in Calu-3 cells, H5N8 replication was found comparable to H1N1, but lower than $\mathrm{H} 5 \mathrm{~N} 1$. Interestingly, the replication of the $\mathrm{H} 5 \mathrm{Nx}$ viruses were also significantly delayed and less efficient (especially during early replication cycles) at $33^{\circ} \mathrm{C}$ than $37^{\circ} \mathrm{C}$.

Table 1. Studies on H5Nx viruses and their utilized models.

\begin{tabular}{|c|c|c|c|}
\hline Virus Strain & Model & Pathology & Study \\
\hline $\begin{array}{c}\text { A/environment/Hong } \\
\text { Kong/WCRB-01/2018(H5N6); } \\
\text { A/spoonbill/HK/17-18259/2017(H5N6); } \\
\text { A/northern pintail/HK/MP692/2016(H5N6); } \\
\text { A/chicken/Egypt/F1366A/2017(H5N8); } \\
\text { A/grey-headed gull/Uganda/200144/2017(H5N8) }\end{array}$ & $\begin{array}{l}\text { Human Airway Organoids and } \\
\text { Alveolar Epithelial Cells }\end{array}$ & $\begin{array}{c}\text { Replicated productively with similar virus titers; Lower } \\
\text { virus titers than human isolates A(H1N1)pdm09, HPAI } \\
\text { A(H5N1) and HPAI A(H5N6); Differential cellular tropism; } \\
\text { Induced low levels of pro-inflammatory cytokines and } \\
\text { chemokines; Zoonotic potential but low transmissibility } \\
\text { among humans }\end{array}$ & [22] \\
\hline \multirow{3}{*}{$\begin{array}{c}\text { A/northern } \\
\text { pintail/Washington/40964/2014(H5N2); } \\
\text { A/gyrfalcon/Washington/41088-6/2014(H5N8) }\end{array}$} & Mice & Cause severe disease at high doses & \multirow{3}{*}{ [21] } \\
\hline & Ferret & $\begin{array}{l}\text { Efficient replication in upper and lower respiratory tracts; } \\
\text { Mild clinical symptom; No systemic infection }\end{array}$ & \\
\hline & Calu-3 Cells & $\begin{array}{l}\text { Replication levels lower than virulent } \mathrm{H} 5 \mathrm{~N} 1 \text { but } \\
\text { comparable to human seasonal virus }\end{array}$ & \\
\hline $\begin{array}{l}\text { A/broiler duck/Korea/Buan2/2014(H5N8); } \\
\text { A/breeder duck/Korea/Gochang1/2014(H5N8) }\end{array}$ & Ferret & $\begin{array}{l}\text { Low pathogenesis against ferrets; No systemic infection; } \\
\text { Both isolates did not induce morality and significant } \\
\text { respiratory signs when intranasally challenged; } \\
\text { Buan2-infected ferrets demonstrated dose-dependent } \\
\text { mortality when intratracheally challenged }\end{array}$ & [23] \\
\hline
\end{tabular}


Table 1. Cont.

\begin{tabular}{|c|c|c|c|}
\hline Virus Strain & Model & Pathology & Study \\
\hline \multirow{11}{*}{ A/mallard duck/Korea/W452/2014(H5N8) } & Mice & $\begin{array}{l}\text { Moderately pathogenic; Replicated moderately in lungs; } \\
\text { Limited tissue tropism, particularly brain tissues; Less } \\
\text { pathogenic than H5N1 isolates; When inoculated } \\
\text { intranasally, resulted in body weight reduction of } 6 \% \text { and } \\
40 \% \text { lethality within } 14 \text { days }\end{array}$ & \multirow{11}{*}{ [24] } \\
\hline & Ferret & $\begin{array}{l}\text { Induced moderate nasal wash titers; Shed from upper } \\
\text { respiratory tract; Replicated in lungs and spleen, recovered } \\
\text { from brain, liver and intestine; Transiently evaluated body } \\
\text { temperature without notable signs of illness when } \\
\text { intranasally inoculated }\end{array}$ & \\
\hline & Chicken & $\begin{array}{l}\text { Highly pathogenic, exhibiting disease signs; Lethal; } \\
\text { Replicated systemically }\end{array}$ & \\
\hline & Duck & $\begin{array}{l}\text { Severe-to-moderate signs of infection; Attenuated; } \\
\text { Efficiently transmitted; } 17 \% \text { succumbed to infection when } \\
\text { oronasally infected; High levels of virus replication in } \\
\text { lungs, hearts and intestines are compared to oropharynx } \\
\text { and cloaca; Not found in brain tissue samples }\end{array}$ & \\
\hline & Dogs & $\begin{array}{l}\text { No efficient replication in upper nasal cavity and visceral } \\
\text { tissues; No observable signs of illness }\end{array}$ & \\
\hline & Cats & Transient fever; Marginal weight loss & \\
\hline & MDCK Cells & $\begin{array}{l}\text { Form smaller plaques than } \mathrm{H} 5 \mathrm{~N} 1 \text { isolates; Spherical virus } \\
\text { particles under transmission electron microscopy }\end{array}$ & \\
\hline & SPF Eggs & $\begin{array}{l}\text { Grows more rapidly than H5N1 isolate with exception of } \\
\text { En/W149(H5N1) with PB2627K mutation }\end{array}$ & \\
\hline & Differentiated Primary CELu & \multirow{2}{*}{ Lower replication titers than En/W149(H5N1) } & \\
\hline & NHBE & & \\
\hline & $\begin{array}{l}\text { Human Nasal Respiratory } \\
\text { Epithelium and Lung Tissues }\end{array}$ & $\begin{array}{l}\text { Replication titers comparable to HPAI A(H5N1); } \\
\text { Attachment to human respiratory tissues }\end{array}$ & \\
\hline A/Chicken/Netherlands/EMC-3/2014(H5N8) & Ferret & $\begin{array}{l}\text { Replicates poorly; Did not develop severe disease or } \\
\text { clinical signs; Lacks ability to transmit airborne }\end{array}$ & [25] \\
\hline $\begin{array}{l}\text { A/MD/Korea/W452/2014 (H5N8); } \\
\text { A/EM/Korea/W149/2006 (H5N1) }\end{array}$ & Mice & $\begin{array}{l}\text { Higher viral transcript and host immune-related genes } \\
\text { expression in H5N8-infected compared to H5N1-infected } \\
\text { mice at 1-day post infection; Lower number of H5N8 genes } \\
\text { at 3- and 7-day post infection than H5N1 }\end{array}$ & {$[26]$} \\
\hline
\end{tabular}

Focusing on the pathogenesis of novel H5N8 isolates (A/broiler duck/Korea/Buan2/2014 and A/breeder duck/Korea/Gochang1/2014), both isolates did not result in mortality and notable respiratory symptoms in intranasally challenged ferrets [23], whereas intratracheally Buan2-infected ferrets exhibited dose-dependent mortality with no systemic infection. Analysis of the European A/Chicken/Netherlands/EMC-3/2014 (H5N8) showed low virulence with no detectable airborne transmission in ferrets [25]. Utilizing highthroughput RNA-sequencing to study differences between A/MD/Korea/W452/2014 (H5N8) and A/EM/Korea/W149/2006 (H5N1) viruses, viral transcripts and host immunerelated genes expression levels were observed to be higher in H5N8-infected than H5N1infected mice at 1-day post infection, but lower at 3- and 7-day post infection [26]. On the other hand, A/mallard duck/Korea/W452/2014(H5N8) was moderately pathogenic with limited tissue tropism in mice [24], inducing moderate levels of nasal wash titers from ferrets, being lethal and replicating systemically in chicken, attenuated but easily transmitted in ducks, with domesticated cats being more susceptible than dogs. Although A/mallard duck/Korea/W452/2014(H5N8) predominantly attaches to avian-like receptors, it can bind human virus-like receptors to replicate in human respiratory tract tissues.

The above studies on the various H5N8 strains show a consensus of moderate pathogenicity without severe disease in low doses for both in vivo mammalian models (mouse and ferrets) despite possible attachment to ex vivo human respiratory tissues with replication titers comparable to HPAI A(H5N1). It is with these findings that interesting insights to $\mathrm{H} 5 \mathrm{~N} 8$ can be made. 


\subsection{Species Jumping from Avian to Humans}

Influenza undergoes antigenic drift and shift [27-29] to change. The more minor changes in antigenic drift arise from host immune response evasion by the surface antigens HA and NA of IAVs (see Figure 2A, [29]). These initially small changes produce closely related IAVs, but can result in minor antigenically different viruses with epidemic potential through accumulation of mutations, keeping the host susceptible to IAVs due to such escape mutations.

\section{(A) Antigenic Drift}

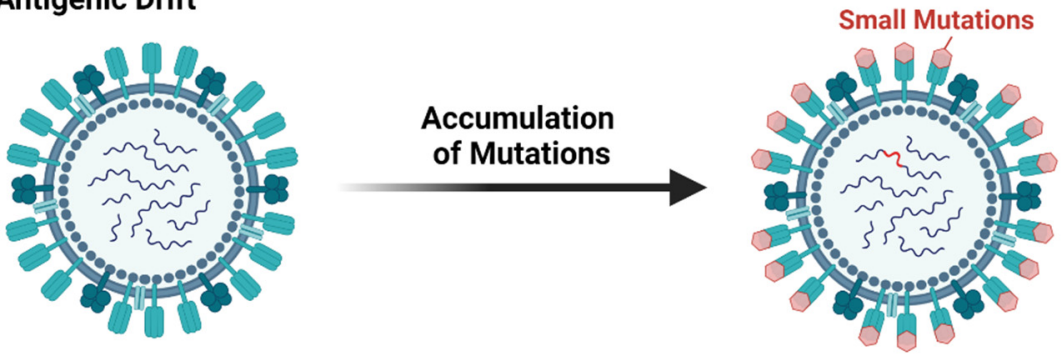

Minor antigenic change with epidemic potential

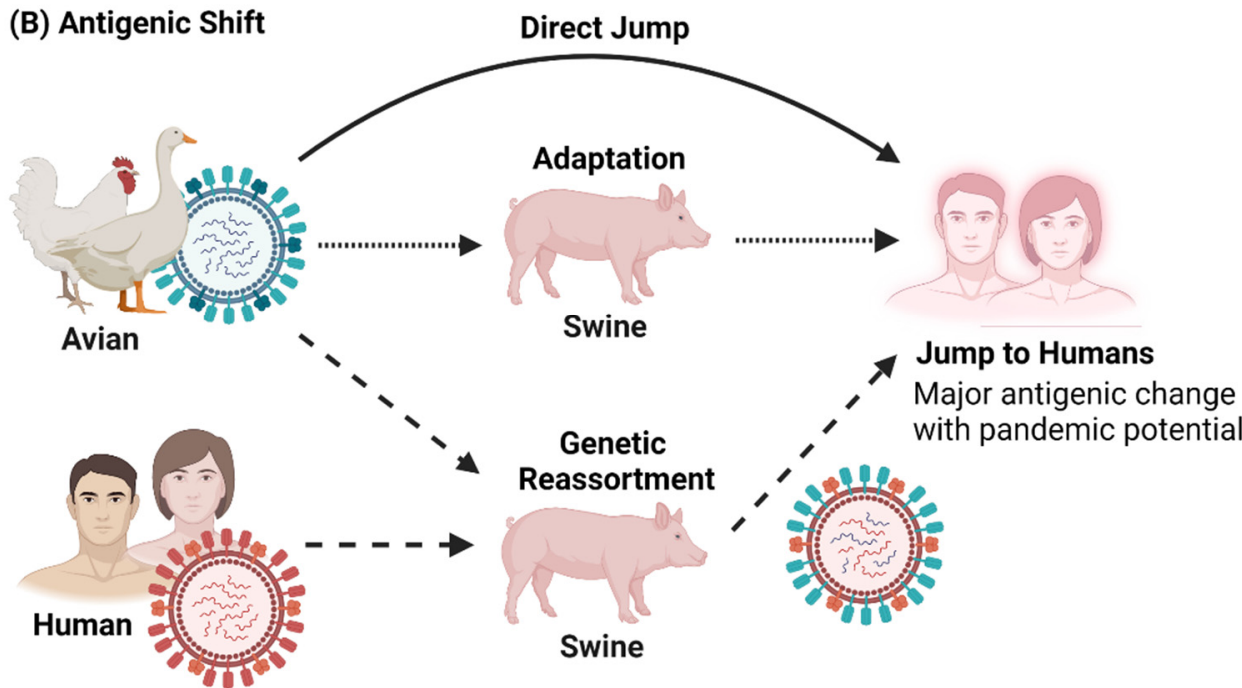

Figure 2. Antigenic Drift and Shift in Influenza A viruses. (A) Antigenic Drift results in minor antigenic changes from an accumulation of mutations. (B) Antigenic Shift results in major antigenic change via direct jump, adaptation and genetic reassortment. Created with BioRender.com.

Commonly resulting from genetic assortment, antigenic shift can occur when two antigenically distinct IAVs co-infect a common cell, allowing reassortment of their genome segments [29]. Such reassortments generate novel viruses of significantly different subtypes through new combinations of surface antigens (HA and/or HA and NA) from the pool of viral genes (see Figure 2B, [27]). The co-infection of an avian and human IAV can give rise to human-adapted viral polymerase antigens which the human host is immunologically naïve to, possibly occurring through an intermediate host such as, swine, which then transmits the human-adapted virus to humans $[30,31]$. In some cases, the species jump from avian to humans can occur directly [32].

While necessary for species jump, reassortment alone is unlikely to result in a human pandemic [29]. It is with the combined accumulation of mutations by the error-prone viral polymerase and selection of viruses that human-human aerosol transmission occurs, thus sowing the seeds of a pandemic. A total of 4 major adaptations from AIV to humanadapted viruses were identified [29,33]: (1) PB2 changes of 590/91SR, E627K and D701N; (2) Binding adaptation of HA $\alpha 2-3$ SA preferences to HA $\alpha 2-6$ SA; (3) Increased virion 
stability from high to low $\mathrm{pH}$ of fusion with increased heat stability; and (4) Evasion of restriction factors. Given that optimal AIVs growth temperature at the avian enteric tract is $\left.\sim 40-41{ }^{\circ} \mathrm{C}\right)$, the ability to replicate in the mammalian upper airway $\left(32{ }^{\circ} \mathrm{C}\right)$ has been proposed as a mammalian adaptation marker $[34,35]$. With an increasing concern of viral receptor-binding adaptations, as illuminated by the COVID-19 pandemic, the receptorbinding adaptations of prior IAV pandemics and potential future adaptations have been extensively reviewed [36].

\subsection{PB2 Subunit on Transmissibility and Virulence}

Apart from receptor-binding adaptations, the PB2 (polymerase basic protein 2) subunit is a major virulence and host transmission determinant [37-41], forming the ribonucleoprotein (RNP) complex with PB1 and PA (see Figure 3A). Due to its cap-snatching mechanism for mRNA transcription, the PB2 subunit has been proposed as a drug target (see Figure 3B, [42-44]). Primarily localized in the nucleus, the PB2 subunit can also accumulate in the mitochondria upon viral entry, interacting with the mitochondrial antiviral signaling protein (MAVS) while inhibiting MAVS-mediated beta interferon (IFN- $\beta$ ) expression [45]. Notably, only PB2 proteins of seasonal human influenza viruses associate with the mitochondria given their asparagine residue at amino acid residue 9 while the PB2 proteins of other avian influenzas viruses with aspartic acid do not [45].

(A)

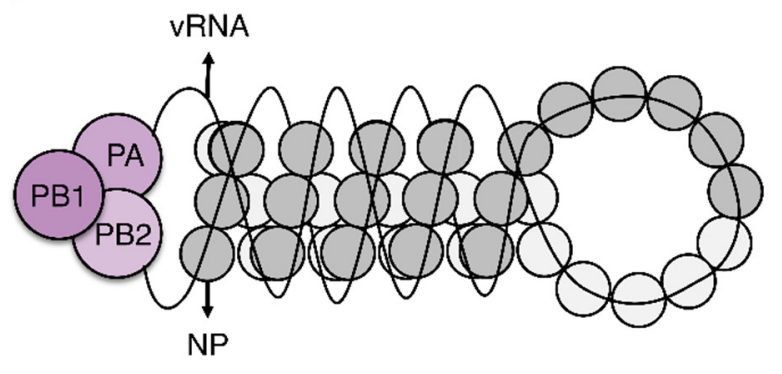

(B)

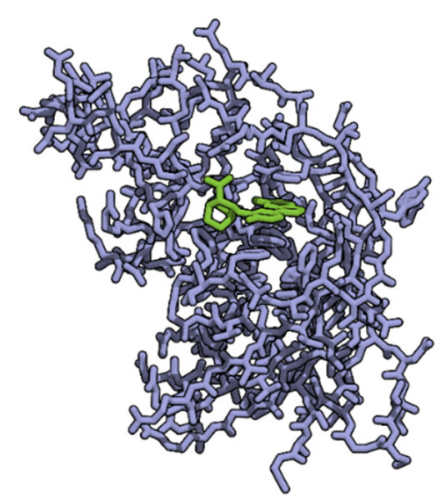

Figure 3. Polymerase basic protein 2 (PB2) subunit. (A) Ribonucleoprotein (RNP) complex comprising of the heterotrimeric complex (PB1, PB2, and PA), nucleoprotein (NP) and viral RNA (vRNA). (B) Influenza A (A/California/07/2009(H1N1)) PB2 complexed with Pimodivir, VX-787 (in green, PDB 7AS0 [42]) modified with QuteMol [46].

The PB2-E627K substitution is a known mammalian signature mutation in IAVs. Deep-sequencing of H7N9 genomes showed genetic tuning of AIV in human hosts with the PB2-E627K substitution, suggesting association with H7N9 pathogenicity [47] and increased viral replication in mice [40,48-51]. Residues 283M and 526R of PB2 were found to synergistically contribute to virulence, with $283 \mathrm{M}$ established to be a mammalianadapted virulence marker [52].

Although the precise mechanisms of these mutations remain unknown, three theories have been previously proposed [47]. Firstly, mutations such as E627K at the basic face of PB2 regulate polymerase activity and viral replication [53], possibly allows it to be catalytic active at the lower temperature of $33{ }^{\circ} \mathrm{C}$ in the human upper respiratory tract $[54,55]$. Secondly, through interactions of the PB2 C-terminus and cytoplasmic importins, PB2 can be independently imported into the nucleus prior to reconstitution of the polymerase unlike PA and PB1 [56]. This increases the charged surface residues (such as the E627K substitution) and thereby the association rate of PB2 to importins [57,58]. Thirdly, the mutations could influence interactions with different host factors, such as ANP32A [59], DEAD box RNA helicase DDX17/p72 [60], RIG-1 [61], and the Wnt/ $\beta$-catenin signaling pathway [62]. 


\section{Towards Pre-Emptive Therapeutics and Prophylactics}

\subsection{Reassortment and Mutational Studies}

Genetic reassortment between avian H5N1 and human influenza viruses have been extensively investigated [63-65]. Coinfecting ferrets with both avian H5N1 (A/Thailand/16/04) and human H3N2 (A/Wyoming/3/03) viruses [63], continued exposure to H5N1 and seasonal influenza viruses was found to increase risk of generating $\mathrm{H} 5$ subtype reassortment viruses that can shed from upper airway secretions. Through reverse genetics, all 254 reassortants between avian H5N1 (A/chicken/South Kalimantan/UT6028/06) and human H3N2 (A/Tokyo/Ut-Sk-1/07) was generated [64], with the A/Tokyo/Ut-Sk-1/07 PB2 protein shown to allow efficient viral RNA transcription through its RNP activity. Furthermore, the reassortment of H5N1 viruses with human influenza viruses (H1N1, H3N2 and pandemic H1N1) in MDCK and human bronchial epithelial cells demonstrated that the neuraminidase and matrix genes of human influenza viruses had the highest genetic compatibility with H5N1 [65].

Certainly, the avian H5N8 virus has been shown to be capable of genetic reassortment with human influenza viruses (H3N2, H1N1 and pandemic H1N1) for viral titers and replication kinetics analysis in vitro using various cell lines [65] and in vivo using mice and ferret models $[63,64]$. Through simulating the genetic of avian H5N8 with other human influenza viruses in vitro reassortment (with emphasis on the PB2 subunit), it is possible to generate a predictive mutation platform like that performed for HIV [66], allowing us to understand their effects on viral replication and transmission,

As with many RNA viruses, Influenza A has low fidelity owing to its error-prone RNAdependent RNA polymerase ( $R \mathrm{dRp}$ ) and lack of proofreading and repair mechanisms during genome replication [67-69]. This explains the mutation rates of A/Puerto Rico/8/1934 H1N1 and A/Hong Kong/4801/2014 (H3N2), which were found to be $1.8 \times 10^{-4}$ and $2.5 \times 10^{-4}$ substitutions/nucleotide/strand copied, respectively, with a transitional bias of 2.7-3.6 [70]. At a genomic level, this rate translates to an average of 2 to 3 mutations in each replicated genome, showing a relatively high amount during infection. Comprehensively mapping avian PB2 adaptation mutations [71], mutations with enhanced growth in human cells properties could be easily identified. Similarly, deep mutational scanning of the human A/Perth/16/2009(H3N2) hemagglutinin [72] can suggest mutational effects in the IAV antigenic drifts, possibly predicting strains heading towards lethal mutagenesis. Early methods to do these have been complicated by different escape mutations from polyclonal human immunity [73] confounding the analysis. Thereby, the use of an innate selection-free system [66] may provide a clearer insight into the influence of natural genetic code biases [74] to get a more accurate mutation rate of antigenic drift as for HIV [75] before in vitro co-infection of other IAVs to study Influenza reassortment.

\subsection{Monitoring through Deep-Sequencing}

The monitoring of emerging strains via deep-sequencing of viral genomes such as that performed on H7N9-infected clinical samples [47] can increase preparedness. PB2-M64T in the Danish novel clade 2.3.4.4b H5N8 viruses was found to be highly conserved in human Influenza A H1N1, H2N2, H3N2 viruses [76,77], in A/barnacle goose/Denmark/141393/2020(H5N8) [78] and A/chicken/Netherlands/20017694-004/2020(H5N8), but not the recent first human infection, A/Astrakhan/3212/2020(H5N8). Through close monitoring, the sequences were mapped to anticipate species jumping [76] from comparing 42 previously identified human-adaptive markers of PB2 sequences.

Following-up on the first human infection of A/Astrakhan/3212/2020(H5N8), whole genome sequence and virus characterization of the human influenza isolate $\mathrm{A} / \mathrm{Astrakhan} /$ 3212/2020(H5N8) and five avian isolates (A/chicken/Astrakhan/321-01/2020, A/chicken/ Astrakhan/321-05/2020, A/chicken/Astrakhan/321-06/2020, A/chicken/Astrakhan/32109/2020, A/chicken/Astrakhan/321-10/2020) [18] were phylogenetically determined. The $\mathrm{HA}$ and NA genes of the human isolate were found to be identical to the avian isolate A/chicken/Astrakhan/321-06/2020(H5N8), with a S28N mutation in the NA that was 
not found in the other four avian isolates. Mutations at this $28 \mathrm{~N}$ site is also present in candidate vaccine viruses but this could be due to a methodological bias introduced by nested PCR [79]. At the HA, A/Astrakhan/3212/2020(H5N8) also had the polybasic proteolytic cleavage site (PLREKRRKR/G), confirming its HPAI virus identity. At the polymerase acidic protein (PA) gene, the human isolate showed the A598T distinction from the avian isolates that while currently having an unknown impact, provides a clue to an important gap on the species differences, not only of the mutation but of the NA gene function differentially in different hosts.

Compared to its closest antigenic reference strain of clade 2.3.4.4. b A/Fujian-Sanyuan/ 21099/2017, the A/Astrakhan/3212/2020 had the T140A substitution in antigenic site A, likely associated with antigenic drift [18]. Both the A/Fujian-Sanyuan/21099/2017 and A/Astrakhan/3212/2020 strains had the same receptor-binding site (RBS) markers and a QS(R)G motif at the RBS associated with an avian-like $\alpha 2,3$-sialic acid receptor-binding preference [80]. Genotypic analysis of A/Astrakhan/3212/2020 also revealed that it did not have mutations associated with reduced susceptibility to NA inhibitors, adamantanes or baloxavir marboxil [81], while phenotypic analysis of both human and avian isolates demonstrated normal susceptibility to oseltamivir and zanamivir.

\subsection{Contribution of Host Proteins}

RNA editing by host proteins in higher eukaryotes can occur, such as those by adenosine deaminases acting on RNA (ADAR) and apolipoprotein B mRNA-editing enzyme catalytic polypeptide (APOBEC), which deaminates adenine (A) to inosine (I), recognized as guanosine $(\mathrm{G})$, and cytidine $(\mathrm{C})$ to uracil $(\mathrm{U})$, recognized as thymine $(\mathrm{T})$ respectively (see Figure 4A,B, [82-87]). A previous study involving H1N1, H3N2, H5N1 and H7N9 in both human (lung and tracheobronchial cells) and avian (ileum and lung tissues) hosts [88] showed strong induction of APOBEC3G but not APOBEC3F by influenza A. This upregulation of APOBEC3G was attributed to the IFN- $\beta$ response, although it did not translate to antiviral activity [89]. Thus, it is of value to understand how the mutation rate and mutational bias influenced by these host proteins can contribute to $\mathrm{H} 5 \mathrm{~N} 8$ viral proteins species jump and inhibition of viral infections [90]. The inclusion of zinc-finger antiviral protein (ZAP, see Figure 4C), given its ability to recognize RNA and antiviral activity of diverse RNA viruses (including IAV) through depleting vRNAs with high frequencies of CG dinucleotides [91-94] may also provide deeper host-viral interactions. Aside from the discussed host proteins, understanding restriction factors and their mechanism of action are key to the development of therapeutics and prophylactics [95], as exemplified by the autophagy regulator TBC1D5 which controls IAV replication and promote lysosomal targeting of its M2 protein [96] and a natural variant (D130A) in ANP32B which impairs dimeric influenza virus polymerase formation and viral replication [97].

\subsection{Design-Build-Test-Learn Cycle for H5N8}

Learning and adapting from the design-build-test-learn (DBTL) cycle commonly utilized in microbial engineering [98,99], a framework (exemplified in Figure 5) can guide therapeutics and prophylactics development [100]. This has been previously proposed and extensively reviewed for the identification and production of novel active flavonoids against the main protease of SARS-CoV-2 [101] and more recently, towards building a sustainable vaccines industry away from conventional approaches through designing and prototyping of vaccines in biofoundries [102]. 

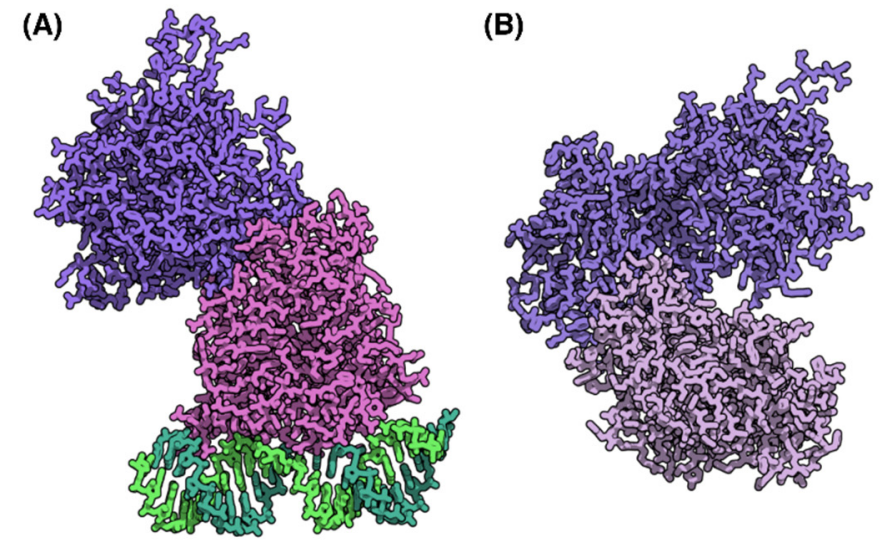

(C)

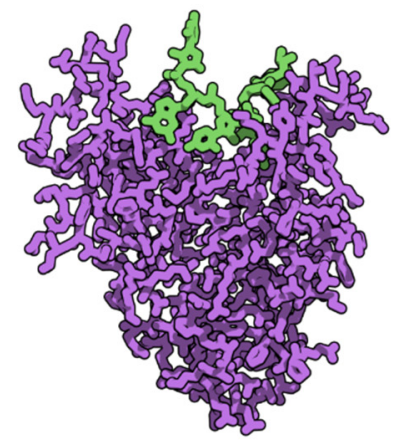

Figure 4. Host Proteins with RNA editing functions. (A) Human Adenosine Deaminase Acting on dsRNA (in purple) bound to dsRNA (in green, PDB 5ED1, [83]). (B) Apolipoprotein B mRNA-editing enzyme, catalytic polypeptide-like 3G (APOBEC3G, PDB 6P3X, [82]). (C) Zinc-finger antiviral protein (ZAP) bound to RNA (in green, PDB 6L1W, [93]). Protein structures modified with QuteMol [46].

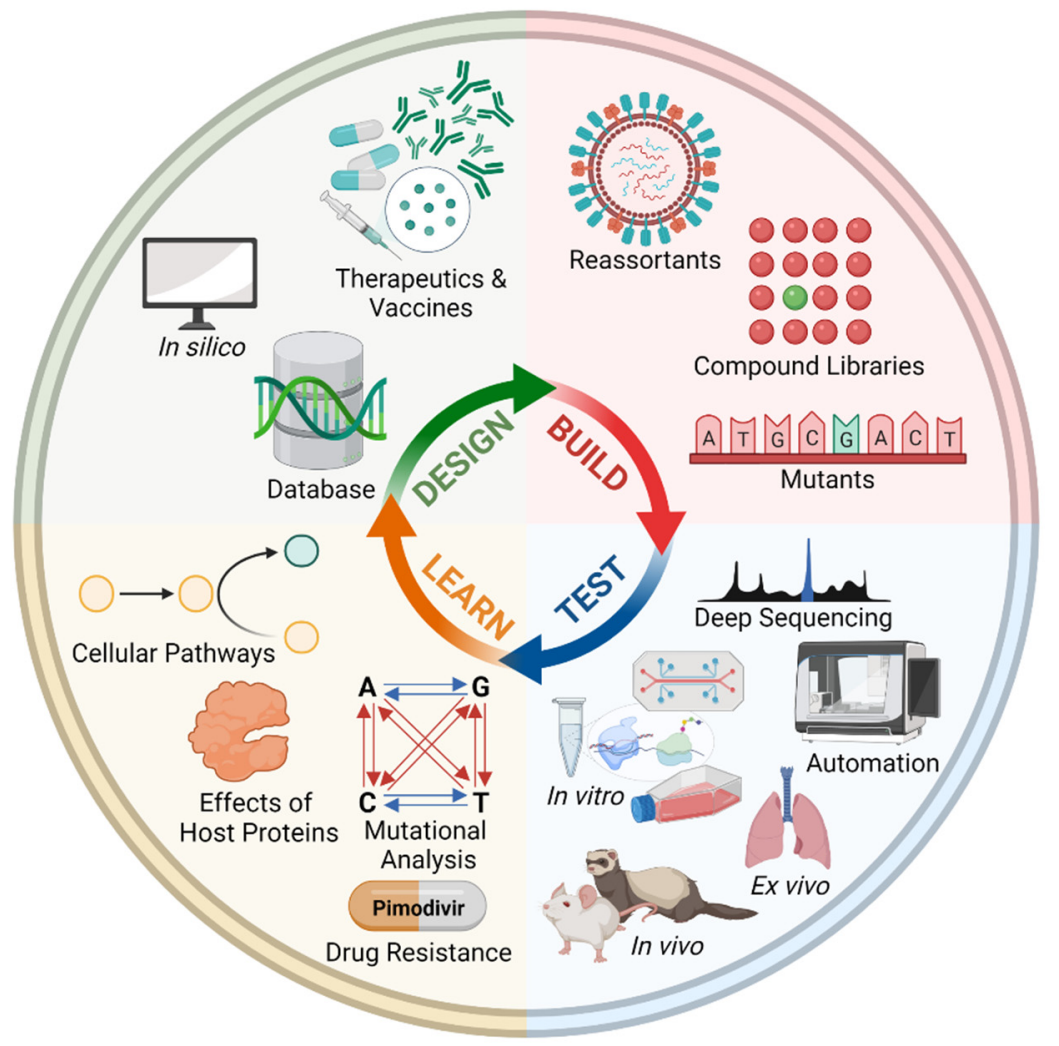

Figure 5. Framework of a design-build-test-learn (DBTL) for H5N8 to complement surveillance. Created with BioRender.com.

Through an understanding of $\mathrm{H} 5 \mathrm{~N} 8$, there is transferable understanding and insight for other influenza A viruses such as the first avian influenza A(H10N3) human infection in Zhenjiang City, Jiangsu Province, China, reported in May 2021 [103,104]. Libraries of possible mutations, reassortants and compounds can be combinatorically and simultaneously tested and validated through in vitro, in vivo and ex vivo experimentations (as listed in Table 1). Aside from models previously discussed, a human lung airway-on-a-chip model to study emerging influenza virus variants has been recently established, demonstrating the emergence of clinically associated drug resistance mutations in the presence of antiviral drugs [105]. Through rational experimental designing, this developmental process can 
be automated. Additionally, given the advances in sequencing technologies, a previously built pipeline has been shown to discriminate clonotypes of IAV genes using the MinION platform [106], with implications on advancing viral quasispecies investigations [107] and as part of global surveillance. Considering host proteins and restriction factors, predictions of mutations (as previously applied to HIV-1 [66]) can provide insights to emerging drug resistance (of available and novel drugs) and cellular pathways. It should be noted that there would be two aspects to such experimental mutational platform for Influenza. In studying the innate RdRp bias and hotspots in antigenic drift, the method applied for HIV would suffice. However, for studying antigenic shift, in vitro co-infection with other IAV subtypes would need to be performed with a screening for interactions with anti-serums or with other interventions to study escape variants. For the latter, there is much to do, perhaps best and most easily performed at an in silico level for cost-effectiveness and safety reasons. Moreover, such computational analysis can also support intervention strategies.

With proteomics data of IAVs [108,109], novel drug targets and drug repurposing strategies can be identified as previously applied to SARS-CoV-2 [110]. Taking a host-directed therapy approach [111], the constructed SARS-CoV-2-induced protein artificial neural network cross-examined disease signatures and approved drugs, identifying 200 drugs with 40 already in clinical trials and 2 (proguanil and sulfasalazine) demonstrated to inhibit replication [110]. Applying such an approach to the H5N8 subtype and extended IAVs, understanding these metabolic perturbations are key in identifying novel and repurposing existing drugs to target them [112]. Some of these cellular pathways that are hijacked during influenza infections include the metabolic pathways and intracellular signaling cascades NF-kB, PI3K/Akt, MAPK, PKC/PKR and TLR/RIG-I [112,113].

With feedback from the already huge databases available for influenza viruses [16,114-118], the framework can leverage upon in silico and machine learning prediction methods. One example is to utilize the stacking model to differentiate mutation patterns and antigenicity between epidemic and pandemic strains for influenza surveillance, as was applied to H1N1 viruses [119]. Sequence-only fitness estimates, applied to the seasonal H3N2 influenza virus, could also allow a forecasting framework integrating estimates of phenotypic measures of antigenic drift and functional constraint to be built [120], amongst the many available methods. An example is Tempel, a time-series mutation prediction model for influenza A viruses employed recurrent neural networks with attention mechanisms for historical glycoprotein hemagglutinin sequences to predict mutations likely to occur in flu seasons [121].

Combined, the framework guides the development of antiviral therapeutics and vaccines, that includes small molecules [122-124], antibodies, and universal influenza vaccines [125]. One example of such rational drug designs is JNJ7918, an oral small molecule mimicking broadly neutralizing antibodies, that was improved for binding and virus neutralization, and further refined for stability and oral bioavailability [124]. Another oral inhibitor is Pimodivir (VH-787, Figure 3B), a novel inhibitor of influenza virus replication, inhibits cap binding to the PB2 subunit [126] and recently entered the third phase of clinical trials [42]. However, several major drug-mutations in the PB2 subunit has already been observed (such as F404Y and M431I and H357N, [42]) to show resistance. Thus, the mapping of PB2 single-amino-mutations could prepare against Pimodivir resistance [127]. For it is through predicting and understanding mutations that future inhibitors (or improvement on existing inhibitors such as Pimodivir) which could possibly withstand drug-resistance mutations [127] be better designed. This combinatorial approach of computational and experimental research has been previously applied in the COVID-19 pandemic, for both drug repurposing [128] and synergistic drug combinations [129]. Such knowledge, when coupled with antibody engineering [130], could also lead to development of better neutralizing antibodies, particularly if they are of mucosal antibodies of IgA [131] or even IgE [132,133], capable of recognizing superantigen elements [134] as the SARS-CoV-2 spike [135].

Since escape mutations also impact vaccines, the assessment of safety and immunogenicity is also important, as was performed for the first-in-human universal flu vaccine 
Phase I trial of FluMos-v1 [136], which is a quadrivalent influenza nanoparticle vaccine containing $20 \mathrm{HA}$ glycoprotein trimers that induced broad protection in mice, ferrets and monkeys [137].

Given that nucleoside analogues can exhibit a broad-spectrum antiviral effect in lethal mutagenesis $[138,139]$ by augmenting mutation rates towards error catastrophe [140], the trajectory and mutational patterns of the viral mutation have clear implication in unraveling such effects. Three nucleoside analogues, ribavirin, 5-azacytidine and 5-fluorouracil active against seasonal H3N2 (A/Panama/2007/1999(H3N2) and A/Wyoming/03/2003(H3N2)) and laboratory-adapted H1N1 (A/Puerto Rico/8/1934(H1N1) and A/WSN/33(H1N1)), promoted the increase in defective viral particles [141]. The testing of these nucleoside analogues against $\mathrm{H} 5 \mathrm{~N} 8$ viruses in the framework could allow assessment of their use as a broad-spectrum anti-influenza drug. With its patent pending, a novel class of immunostimulatory RNAs (isRNAs) simulating Type I Interferon (IFN-1) response [142] inhibited infection of multiple respiratory viruses (including SARS-CoV-2, influenza, and common cold viruses) with $>95 \%$ influenza inhibition and $>99 \%$ SARS-CoV-2 inhibition in vitro in human lung epithelial cells, and inhibition of SARS-CoV-2 infection in vivo in hamsters.

Since different viruses have different mutational methods and rates, where reassortment occurs in segmented RNA viruses and recombination for all RNA viruses ([143], see Figure 6), there is room for cross-application and cross-validation of the computational and experimental prediction methods. By adapting this framework to substitute reassortants with recombinants, it can potentially be applied to other viruses which undergo recombination such as Human Immunodeficiency Viruses (HIV) $[144,145]$ and Enterovirus D68 (EV-D68) [146].

(A)

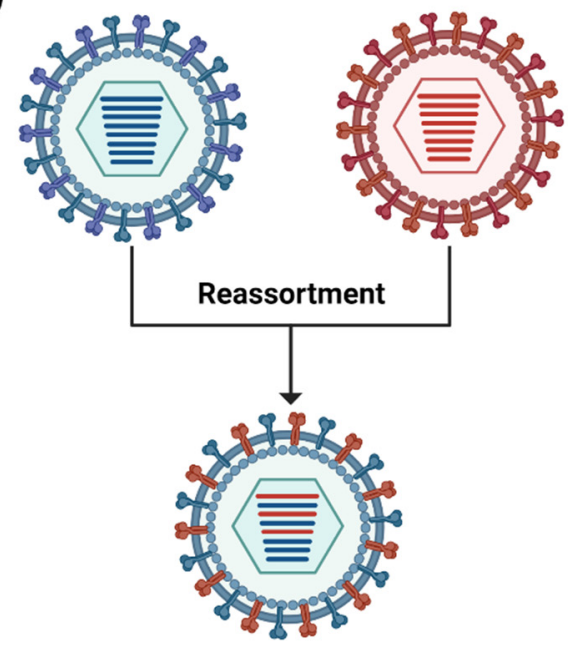

E.g. Influenza Viruses
I (B)

1
1
1
1
1
1
1
1
1
1
1
1
1
1
1

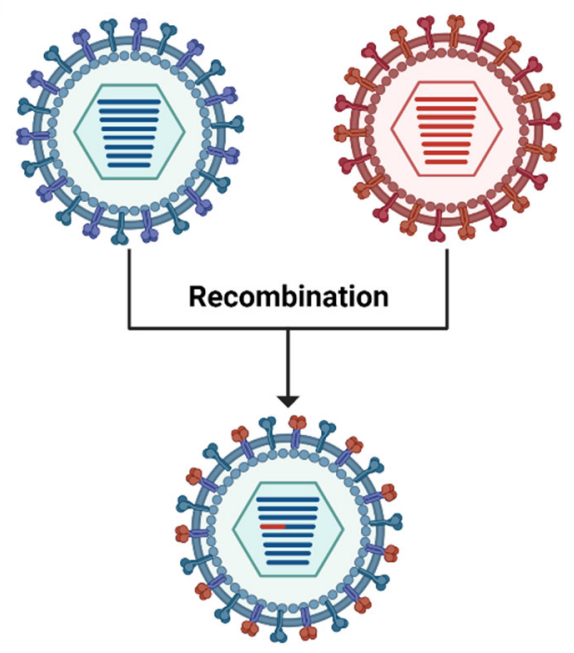

E.g. Human Immunodeficiency Virus (HIV) and Enterovirus D68 (EV-D68)

Figure 6. Modes of genetic modification by viruses. (A) Reassortment, which only occurs in segmented RNA viruses such as Influenza viruses where two antigenically distinct IAVs co-infect a common cell and reassort their genome segments.

(B) Recombination, which occurs in all RNA viruses such as Human Immunodeficiency Virus (HIV) and Enterovirus D68 (EV-D68). Created with BioRender.com.

\section{Conclusions}

With the first human transmission of influenza H5N8 in Astrakhan Oblast, Russia, the need to understand this emerging highly pathogenic avian virus and its possible mechanisms of species jumping to avert disastrous pandemics is demonstrated. Through the incorporation of novel methods in a design-build-test-learn (DBTL) cycle, gaps in understanding Influenza and other viruses can be made through models complemented 
with deep sequencing and automation. In combination with in silico prediction methods, this knowledge can be applied towards development of antiviral therapeutics and vaccines.

Author Contributions: Conceptualization, J.Y.Y. and S.K.-E.G.; writing—original draft preparation, J.Y.Y.; writing-review and editing, J.Y.Y. and S.K.-E.G. All authors have read and agreed to the published version of the manuscript.

Funding: Authors are funded by the National Research Foundation Singapore grant to Experimental Drug Development Centre, A*STAR.

Institutional Review Board Statement: Not applicable.

Informed Consent Statement: Not applicable.

Data Availability Statement: No new data were created or analyzed in this study. Data sharing is not applicable to this article.

Acknowledgments: Figures were created with BioRender.com, accessed on 20 October 2021. J.Y.Y. would like to thank L.S. for her helpful comments and suggestions. An earlier version of the manuscript was submitted as part of the coursework for the undergraduate module: Researching biology and health sciences (SXL390) at The Open University.

Conflicts of Interest: The authors declare no conflict of interest.

\section{References}

1. Centers for Disease Control and Prevention. Types of Influenza Viruses. Available online: https://www.cdc.gov/flu/about/ viruses/types.htm (accessed on 2 April 2021).

2. Bouvier, N.M.; Palese, P. The biology of influenza viruses. Vaccine 2008, 26, D49-D53. [CrossRef]

3. McAuley, J.L.; Gilbertson, B.P.; Trifkovic, S.; Brown, L.E.; McKimm-Breschkin, J.L. Influenza Virus Neuraminidase Structure and Functions. Front. Microbiol. 2019, 10. [CrossRef] [PubMed]

4. Kosik, I.; Yewdell, J.W. Influenza Hemagglutinin and Neuraminidase: Yin-Yang Proteins Coevolving to Thwart Immunity. Viruses 2019, 11, 346. [CrossRef] [PubMed]

5. Dou, D.; Revol, R.; Östbye, H.; Wang, H.; Daniels, R. Influenza A Virus Cell Entry, Replication, Virion Assembly and Movement. Front. Immunol. 2018, 9. [CrossRef] [PubMed]

6. Mostafa, A.; Abdelwhab, E.M.; Mettenleiter, T.C.; Pleschka, S. Zoonotic Potential of Influenza A Viruses: A Comprehensive Overview. Viruses 2018, 10, 497. [CrossRef]

7. Nuñez, I.A.; Ross, T.M. A review of H5Nx avian influenza viruses. Ther. Adv. Vaccines Immunother. 2019, 7. [CrossRef]

8. Samji, T. Influenza A: Understanding the viral life cycle. Yale. J. Biol. Med. 2009, 82, 153-159. Available online: https: //www.ncbi.nlm.nih.gov/pmc/articles/PMC2794490/pdf/yjbm_82_4_153.pdf (accessed on 2 April 2021).

9. Hussain, M.; Galvin, H.D.; Haw, T.Y.; Nutsford, A.N.; Husain, M. Drug resistance in influenza A virus: The epidemiology and management. Infect. Drug Resist. 2017, 10, 121-134. [CrossRef]

10. Centers for Disease Control and Prevention. 2009 H1N1 Pandemic. Available online: https://www.cdc.gov/flu/pandemicresources/2009-h1n1-pandemic.html (accessed on 2 April 2021).

11. World Health Organization. Human Infection with Avian Influenza A(H5N8)-the Russian Federation. Available online: https://www.who.int/csr/don/26-feb-2021-influenza-a-russian-federation/en/ (accessed on 28 February 2021).

12. Lee, Y.-J.; Kang, H.-M.; Lee, E.-K.; Song, B.-M.; Jeong, J.; Kwon, Y.-K.; Kim, H.-R.; Lee, K.-J.; Hong, M.-S.; Jang, I.; et al. Novel Reassortant Influenza A(H5N8) Viruses, South Korea, 2014. Emerg. Infect. Dis. 2014, 20, 1086. [CrossRef] [PubMed]

13. World Organisation for Animal Health. Chapter 3.3.4. Avian Influenza (Including Infection with High Pathogenicity Avian Influenza Viruses). Available online: https://www.oie.int/fileadmin/Home/eng/Health_standards/tahm/3.03.04_AI.pdf (accessed on 19 October 2021).

14. World Organisation for Animal Health. Updates on the spread of H5N8 Avian Influenza from an African Perspective. Available online: https://rr-africa.oie.int/en/news/updates-on-the-spread-of-h5n8-avian-influenza-from-an-african-perspective/ (accessed on 28 February 2021).

15. Greene, J.L. Update on the Highly-Pathogenic Avian Influenza Outbreak of 2014-2015. Available online: https://fas.org/sgp/ $\mathrm{crs} / \mathrm{misc} /$ R44114.pdf (accessed on 28 February 2021).

16. Shu, Y.; McCauley, J. GISAID: Global initiative on sharing all influenza data-from vision to reality. Eurosurveillance 2017, $22,30494$. [CrossRef]

17. The Global Consortium for H5N8 and Related Influenza Viruses. Role for Migratory Wild Birds in the Global Spread of Avian Influenza H5N8. Science 2016, 354, 213-217. [CrossRef]

18. Pyankova, O.G.; Susloparov, I.M.; Moiseeva, A.A.; Kolosova, N.P.; Onkhonova, G.S.; Danilenko, A.V.; Vakalova, E.V.; Shendo, G.L.; Nekeshina, N.N.; Noskova, L.N.; et al. Isolation of clade 2.3.4.4b A(H5N8), a highly pathogenic avian influenza virus, from a worker during an outbreak on a poultry farm, Russia, December 2020. Eurosurveillance 2021, 26, 2100439. [CrossRef] 
19. Yamaji, R.; Saad, M.D.; Davis, C.T.; Swayne, D.E.; Wang, D.; Wong, F.Y.K.; McCauley, J.W.; Peiris, J.S.M.; Webby, R.J.; Fouchier, R.A.M.; et al. Pandemic potential of highly pathogenic avian influenza clade 2.3.4.4 A(H5) viruses. Rev. Med. Virol. 2020, 30, e2099. [CrossRef]

20. Shi, W.; Gao, G.F. Emerging H5N8 avian influenza viruses. Science 2021, 372, 784-786. [CrossRef]

21. Pulit-Penaloza, J.A.; Sun, X.; Creager, H.M.; Zeng, H.; Belser, J.A.; Maines, T.R.; Tumpey, T.M. Pathogenesis and Transmission of Novel Highly Pathogenic Avian Influenza H5N2 and H5N8 Viruses in Ferrets and Mice. J. Virol. 2015, 89, 10286-10293. [CrossRef]

22. Bui, C.H.T.; Kuok, D.I.T.; Yeung, H.; Ng, K.-C.; Chu, D.K.W.; Webby, R.; Nicholls, J.; Peiris, J.S.M.; Hui, K.P.Y.; Chan, M.C.W. Risk Assessment for Highly Pathogenic Avian Influenza A(H5N6/H5N8) Clade 2.3.4.4 Viruses. Emerg. Infect. Dis. J. 2021, 27, 2619. [CrossRef] [PubMed]

23. Kim, H.M.; Kim, C.-K.; Lee, N.-J.; Chu, H.; Kang, C.; Kim, K.; Lee, J.-Y. Pathogenesis of novel reassortant avian influenza virus A (H5N8) Isolates in the ferret. Virology 2015, 481, 136-141. [CrossRef] [PubMed]

24. Kim, Y.-I.; Pascua, P.N.Q.; Kwon, H.-I.; Lim, G.-J.; Kim, E.-H.; Yoon, S.-W.; Park, S.-J.; Kim, S.M.; Choi, E.-J.; Si, Y.-J.; et al. Pathobiological features of a novel, highly pathogenic avian influenza A(H5N8) virus. Emerg. Microbes Infect. 2014, 3. [CrossRef] [PubMed]

25. Richard, M.; Herfst, S.; van den Brand, J.M.A.; Lexmond, P.; Bestebroer, T.M.; Rimmelzwaan, G.F.; Koopmans, M.; Kuiken, T.; Fouchier, R.A.M. Low Virulence and Lack of Airborne Transmission of the Dutch Highly Pathogenic Avian Influenza Virus H5N8 in Ferrets. PLoS ONE 2015, 10, e0129827. [CrossRef] [PubMed]

26. Park, S.-J.; Kumar, M.; Kwon, H.-i.; Seong, R.-K.; Han, K.; Song, J.-m.; Kim, C.-J.; Choi, Y.-K.; Shin, O.S. Dynamic changes in host gene expression associated with H5N8 avian influenza virus infection in mice. Sci. Rep. 2015, 5, 16512. [CrossRef] [PubMed]

27. Centers for Disease Control and Prevention. How the Flu Virus Can Change: "Drift" and "Shift". Available online: https: //www.cdc.gov/flu/about/viruses/change.htm (accessed on 2 April 2021).

28. Taubenberger, J.K.; Kash, J.C. Influenza Virus Evolution, Host Adaptation, and Pandemic Formation. Cell Host Microbe 2010, 7, 440-451. [CrossRef]

29. Long, J.S.; Mistry, B.; Haslam, S.M.; Barclay, W.S. Host and viral determinants of influenza A virus species specificity. Nat. Rev. Microbiol. 2019, 17, 67-81. [CrossRef]

30. Bourret, V.; Lyall, J.; Frost, S.D.W.; Teillaud, A.; Smith, C.A.; Leclaire, S.; Fu, J.; Gandon, S.; Guérin, J.-L.; Tiley, L.S. Adaptation of avian influenza virus to a swine host. Virus Evol. 2017, 3. [CrossRef] [PubMed]

31. Rajao, D.S.; Vincent, A.L.; Perez, D.R. Adaptation of Human Influenza Viruses to Swine. Front. Vet. Sci. 2019, 5. [CrossRef] [PubMed]

32. Centers for Disease Control and Prevention. Spread of Bird Flu Viruses between Animals and People. Available online: https:/ / www.cdc.gov/flu/avianflu/virus-transmission.htm (accessed on 2 April 2021).

33. Shi, Y.; Wu, Y.; Zhang, W.; Qi, J.; Gao, G.F. Enabling the "host jump": Structural determinants of receptor-binding specificity in influenza A viruses. Nat. Rev. Microbiol. 2014, 12, 822-831. [CrossRef] [PubMed]

34. Zeng, H.; Goldsmith, C.S.; Maines, T.R.; Belser, J.A.; Gustin, K.M.; Pekosz, A.; Zaki, S.R.; Katz, J.M.; Tumpey, T.M. Tropism and Infectivity of Influenza Virus, Including Highly Pathogenic Avian H5N1 Virus, in Ferret Tracheal Differentiated Primary Epithelial Cell Cultures. J. Virol. 2013, 87, 2597-2607. [CrossRef]

35. Van Hoeven, N.; Pappas, C.; Belser, J.A.; Maines, T.R.; Zeng, H.; García-Sastre, A.; Sasisekharan, R.; Katz, J.M.; Tumpey, T.M. Human HA and polymerase subunit PB2 proteins confer transmission of an avian influenza virus through the air. Proc. Natl. Acad. Sci. USA 2009, 106, 3366-3371. [CrossRef]

36. Thompson, A.J.; Paulson, J.C. Adaptation of influenza viruses to human airway receptors. J. Biol. Chem. 2021, 296. [CrossRef]

37. Subbarao, E.K.; London, W.; Murphy, B.R. A single amino acid in the PB2 gene of influenza A virus is a determinant of host range. J. Virol. 1993, 67, 1761-1764. [CrossRef]

38. Mehle, A.; Doudna, J.A. An Inhibitory Activity in Human Cells Restricts the Function of an Avian-like Influenza Virus Polymerase. Cell Host Microbe 2008, 4, 111-122. [CrossRef]

39. Labadie, K.; Dos Santos Afonso, E.; Rameix-Welti, M.-A.; van der Werf, S.; Naffakh, N. Host-range determinants on the PB2 protein of influenza A viruses control the interaction between the viral polymerase and nucleoprotein in human cells. Virology 2007, 362, 271-282. [CrossRef]

40. Hatta, M.; Gao, P.; Halfmann, P.; Kawaoka, Y. Molecular Basis for High Virulence of Hong Kong H5N1 Influenza A Viruses. Science 2001, 293, 1840-1842. [CrossRef]

41. Almond, J.W. A single gene determines the host range of influenza virus. Nature 1977, 270, 617-618. [CrossRef] [PubMed]

42. Gregor, J.; Radilová, K.; Brynda, J.; Fanfrlík, J.; Konvalinka, J.; Kožíšek, M. Structural and Thermodynamic Analysis of the Resistance Development to Pimodivir (VX-787), the Clinical Inhibitor of Cap Binding to PB2 Subunit of Influenza A Polymerase. Molecules 2021, 26, 1007. [CrossRef]

43. Guilligay, D.; Tarendeau, F.; Resa-Infante, P.; Coloma, R.; Crepin, T.; Sehr, P.; Lewis, J.; Ruigrok, R.W.H.; Ortin, J.; Hart, D.J.; et al. The structural basis for cap binding by influenza virus polymerase subunit PB2. Nat. Struct. Mol. Biol. 2008, 15, 500-506. [CrossRef] [PubMed]

44. Severin, C.; Rocha de Moura, T.; Liu, Y.; Li, K.; Zheng, X.; Luo, M. The cap-binding site of influenza virus protein PB2 as a drug target. Acta Crystallogr. Sect. D 2016, 72, 245-253. [CrossRef] 
45. Graef, K.M.; Vreede, F.T.; Lau, Y.-F.; McCall, A.W.; Carr, S.M.; Subbarao, K.; Fodor, E. The PB2 Subunit of the Influenza Virus RNA Polymerase Affects Virulence by Interacting with the Mitochondrial Antiviral Signaling Protein and Inhibiting Expression of Beta Interferon. J. Virol. 2010, 84, 8433-8445. [CrossRef] [PubMed]

46. Tarini, M.; Cignoni, P.; Montani, C. Ambient Occlusion and Edge Cueing for Enhancing Real Time Molecular Visualization. IEEE Trans. Vis. Comput. Graph. 2006, 12, 1237-1244. [CrossRef]

47. Liu, W.J.; Li, J.; Zou, R.; Pan, J.; Jin, T.; Li, L.; Liu, P.; Zhao, Y.; Yu, X.; Wang, H.; et al. Dynamic PB2-E627K substitution of influenza H7N9 virus indicates the in vivo genetic tuning and rapid host adaptation. Proc. Natl. Acad. Sci. USA 2020, 117, 23807. [CrossRef] [PubMed]

48. Shinya, K.; Hamm, S.; Hatta, M.; Ito, H.; Ito, T.; Kawaoka, Y. PB2 amino acid at position 627 affects replicative efficiency, but not cell tropism, of Hong Kong H5N1 influenza A viruses in mice. Virology 2004, 320, 258-266. [CrossRef]

49. Lu, X.; Tumpey, T.M.; Morken, T.; Zaki, S.R.; Cox, N.J.; Katz, J.M. A Mouse Model for the Evaluation of Pathogenesis and Immunity to Influenza A (H5N1) Viruses Isolated from Humans. J. Virol. 1999, 73, 5903-5911. [CrossRef]

50. Hatta, M.; Hatta, Y.; Kim, J.H.; Watanabe, S.; Shinya, K.; Nguyen, T.; Lien, P.S.; Le, Q.M.; Kawaoka, Y. Growth of H5N1 Influenza A Viruses in the Upper Respiratory Tracts of Mice. PLoS Pathog. 2007, 3, e133. [CrossRef] [PubMed]

51. Fornek, J.L.; Gillim-Ross, L.; Santos, C.; Carter, V.; Ward, J.M.; Cheng, L.I.; Proll, S.; Katze, M.G.; Subbarao, K. A Single-AminoAcid Substitution in a Polymerase Protein of an H5N1 Influenza Virus Is Associated with Systemic Infection and Impaired T-Cell Activation in Mice. J. Virol. 2009, 83, 11102-11115. [CrossRef] [PubMed]

52. Wang, X.; Chen, S.; Wang, D.; Zha, X.; Zheng, S.; Qin, T.; Ma, W.; Peng, D.; Liu, X. Synergistic effect of PB2 283M and 526R contributes to enhanced virulence of H5N8 influenza viruses in mice. Vet. Res. 2017, 48, 67. [CrossRef] [PubMed]

53. Kirui, J.; Bucci, M.D.; Poole, D.S.; Mehle, A.; Kirkegaard, K. Conserved Features of the PB2 627 Domain Impact Influenza Virus Polymerase Function and Replication. J. Virol. 2014, 88, 5977-5986. [CrossRef]

54. Massin, P.; Werf, S.v.d.; Naffakh, N. Residue 627 of PB2 Is a Determinant of Cold Sensitivity in RNA Replication of Avian Influenza Viruses. J. Virol. 2001, 75, 5398-5404. [CrossRef] [PubMed]

55. Aggarwal, S.; Dewhurst, S.; Takimoto, T.; Kim, B. Biochemical Impact of the Host Adaptation-associated PB2 E627K Mutation on the Temperature-dependent RNA Synthesis Kinetics of Influenza A Virus Polymerase Complex. J. Biol. Chem. 2011, 286, 34504-34513. [CrossRef] [PubMed]

56. Tarendeau, F.; Boudet, J.; Guilligay, D.; Mas, P.J.; Bougault, C.M.; Boulo, S.; Baudin, F.; Ruigrok, R.W.H.; Daigle, N.; Ellenberg, J.; et al. Structure and nuclear import function of the C-terminal domain of influenza virus polymerase PB2 subunit. Nat. Struct. Mol. Biol. 2007, 14, 229-233. [CrossRef] [PubMed]

57. Boivin, S.; Hart, D.J. Interaction of the Influenza A Virus Polymerase PB2 C-terminal Region with Importin Isoforms $\alpha$ Provides Insights into Host Adaptation and Polymerase Assembly. J. Biol. Chem. 2011, 286, 10439-10448. [CrossRef]

58. Delaforge, E.; Milles, S.; Bouvignies, G.; Bouvier, D.; Boivin, S.; Salvi, N.; Maurin, D.; Martel, A.; Round, A.; Lemke, E.A.; et al. Large-Scale Conformational Dynamics Control H5N1 Influenza Polymerase PB2 Binding to Importin $\alpha$. J. Am. Chem. Soc. 2015, 137, 15122-15134. [CrossRef]

59. Long, J.S.; Giotis, E.S.; Moncorgé, O.; Frise, R.; Mistry, B.; James, J.; Morisson, M.; Iqbal, M.; Vignal, A.; Skinner, M.A.; et al. Species difference in ANP32A underlies influenza A virus polymerase host restriction. Nature 2016, 529, 101-104. [CrossRef] [PubMed]

60. Bortz, E.; Westera, L.; Maamary, J.; Steel, J.; Albrecht, R.A.; Manicassamy, B.; Chase, G.; Martínez-Sobrido, L.; Schwemmle, M.; García-Sastre, A.; et al. Host- and Strain-Specific Regulation of Influenza Virus Polymerase Activity by Interacting Cellular Proteins. MBio 2011, 2, e00151-11. [CrossRef] [PubMed]

61. Weber, M.; Sediri, H.; Felgenhauer, U.; Binzen, I.; Bänfer, S.; Jacob, R.; Brunotte, L.; García-Sastre, A.; Schmid-Burgk, J.L.; Schmidt, T.; et al. Influenza Virus Adaptation PB2-627K Modulates Nucleocapsid Inhibition by the Pathogen Sensor RIG-I. Cell Host Microbe 2015, 17, 309-319. [CrossRef]

62. Forero, A.; Tisoncik-Go, J.; Watanabe, T.; Zhong, G.; Hatta, M.; Tchitchek, N.; Selinger, C.; Chang, J.; Barker, K.; Morrison, J.; et al. The 1918 Influenza Virus PB2 Protein Enhances Virulence through the Disruption of Inflammatory and Wnt-Mediated Signaling in Mice. J. Virol. 2016, 90, 2240-2253. [CrossRef]

63. Jackson, S.; Hoeven, N.V.; Chen, L.-M.; Maines, T.R.; Cox, N.J.; Katz, J.M.; Donis, R.O. Reassortment between Avian H5N1 and Human H3N2 Influenza Viruses in Ferrets: A Public Health Risk Assessment. J. Virol. 2009, 83, 8131-8140. [CrossRef] [PubMed]

64. Li, C.; Hatta, M.; Nidom, C.A.; Muramoto, Y.; Watanabe, S.; Neumann, G.; Kawaoka, Y. Reassortment between avian H5N1 and human H3N2 influenza viruses creates hybrid viruses with substantial virulence. Proc. Natl. Acad. Sci. USA 2010, 107, 4687-4692. [CrossRef] [PubMed]

65. Schrauwen, E.J.A.; Bestebroer, T.M.; Rimmelzwaan, G.F.; Osterhaus, A.D.M.E.; Fouchier, R.A.M.; Herfst, S. Reassortment between Avian H5N1 and Human Influenza Viruses Is Mainly Restricted to the Matrix and Neuraminidase Gene Segments. PLoS ONE 2013, 8, e59889. [CrossRef] [PubMed]

66. Yeo, J.Y.; Koh, D.W.S.; Yap, P.; Goh, G.R.; Gan, S.K.E. Spontaneous mutations in HIV-1 Gag, Protease, RT p66 in the first replication cycle and how they appear: Insights from an in vitro assay on mutation rates and types. Int. J. Mol. Sci. 2020, 22, 370. [CrossRef] [PubMed]

67. Duffy, S. Why are RNA virus mutation rates so damn high? PLoS Biol. 2018, 16, e3000003. [CrossRef]

68. Steinhauer, D.A.; Domingo, E.; Holland, J.J. Lack of evidence for proofreading mechanisms associated with an RNA virus polymerase. Gene 1992, 122, 281-288. [CrossRef] 
69. Smith, E.C.; Sexton, N.R.; Denison, M.R. Thinking Outside the Triangle: Replication Fidelity of the Largest RNA Viruses. Annu. Rev. Virol. 2014, 1, 111-132. [CrossRef]

70. Pauly, M.D.; Procario, M.C.; Lauring, A.S. A novel twelve class fluctuation test reveals higher than expected mutation rates for influenza A viruses. ELife 2017, 6, e26437. [CrossRef] [PubMed]

71. Soh, Y.Q.S.; Moncla, L.H.; Eguia, R.; Bedford, T.; Bloom, J.D. Comprehensive mapping of adaptation of the avian influenza polymerase protein PB2 to humans. ELife 2019, 8, e45079. [CrossRef] [PubMed]

72. Lee, J.M.; Huddleston, J.; Doud, M.B.; Hooper, K.A.; Wu, N.C.; Bedford, T.; Bloom, J.D. Deep mutational scanning of hemagglutinin helps predict evolutionary fates of human H3N2 influenza variants. Proc. Natl. Acad. Sci. USA 2018, 115, E8276-E8285. [CrossRef]

73. Lee, J.M.; Eguia, R.; Zost, S.J.; Choudhary, S.; Wilson, P.C.; Bedford, T.; Stevens-Ayers, T.; Boeckh, M.; Hurt, A.C.; Lakdawala, S.S.; et al. Mapping person-to-person variation in viral mutations that escape polyclonal serum targeting influenza hemagglutinin. ELife 2019, 8, e49324. [CrossRef]

74. Chan, K.-F.; Koukouravas, S.; Yeo, J.Y.; Koh, D.W.-S.; Gan, S.K.-E. Probability of change in life: Amino acid changes in single nucleotide substitutions. Biosystems 2020, 193-194, 104135. [CrossRef]

75. Yeo, J.Y.; Goh, G.-R.; Su, C.T.-T.; Gan, S.K.-E. The Determination of HIV-1 RT Mutation Rate, Its Possible Allosteric Effects, and Its Implications on Drug Resistance. Viruses 2020, 12, 297. [CrossRef]

76. Wen, L.; Chu, H.; Wong, B.H.-Y.; Wang, D.; Li, C.; Zhao, X.; Chiu, M.-C.; Yuan, S.; Fan, Y.; Chen, H.; et al. Large-scale sequence analysis reveals novel human-adaptive markers in PB2 segment of seasonal influenza A viruses. Emerg. Microbes Infect. 2018, 7, 47. [CrossRef]

77. Finkelstein, D.B.; Mukatira, S.; Mehta, P.K.; Obenauer, J.C.; Su, X.; Webster, R.G.; Naeve, C.W. Persistent Host Markers in Pandemic and H5N1 Influenza Viruses. J. Virol. 2007, 81, 10292-10299. [CrossRef] [PubMed]

78. Liang, Y.; Nissen, J.N.; Krog, J.S.; Breum, S.Ø.; Trebbien, R.; Larsen, L.E.; Hjulsager, C.K. Novel Clade 2.3.4.4b Highly Pathogenic Avian Influenza A H5N8 and H5N5 Viruses in Denmark, 2020. Viruses 2021, 13, 886. [CrossRef]

79. Yu, G.; Fadrosh, D.; Goedert, J.J.; Ravel, J.; Goldstein, A.M. Nested PCR Biases in Interpreting Microbial Community Structure in $16 \mathrm{~S}$ rRNA Gene Sequence Datasets. PLoS ONE 2015, 10, e0132253. [CrossRef] [PubMed]

80. Bi, Y.; Chen, Q.; Wang, Q.; Chen, J.; Jin, T.; Wong, G.; Quan, C.; Liu, J.; Wu, J.; Yin, R.; et al. Genesis, Evolution and Prevalence of H5N6 Avian Influenza Viruses in China. Cell Host Microbe 2016, 20, 810-821. [CrossRef] [PubMed]

81. Omoto, S.; Speranzini, V.; Hashimoto, T.; Noshi, T.; Yamaguchi, H.; Kawai, M.; Kawaguchi, K.; Uehara, T.; Shishido, T.; Naito, A.; et al. Characterization of influenza virus variants induced by treatment with the endonuclease inhibitor baloxavir marboxil. Sci. Rep. 2018, 8, 9633. [CrossRef] [PubMed]

82. Yang, H.; Ito, F.; Wolfe, A.D.; Li, S.; Mohammadzadeh, N.; Love, R.P.; Yan, M.; Zirkle, B.; Gaba, A.; Chelico, L.; et al. Understanding the structural basis of HIV-1 restriction by the full length double-domain APOBEC3G. Nat. Commun. 2020, 11, 632. [CrossRef]

83. Matthews, M.M.; Thomas, J.M.; Zheng, Y.; Tran, K.; Phelps, K.J.; Scott, A.I.; Havel, J.; Fisher, A.J.; Beal, P.A. Structures of human ADAR2 bound to dsRNA reveal base-flipping mechanism and basis for site selectivity. Nat. Struct. Mol. Biol. 2016, $23,426-433$. [CrossRef]

84. Navaratnam, N.; Sarwar, R. An Overview of Cytidine Deaminases. Int. J. Hematol. 2006, 83, 195-200. [CrossRef] [PubMed]

85. Smith, H.C.; Bennett, R.P.; Kizilyer, A.; McDougall, W.M.; Prohaska, K.M. Functions and regulation of the APOBEC family of proteins. Semin. Cell Dev. Biol. 2012, 23, 258-268. [CrossRef]

86. Nishikura, K. Functions and Regulation of RNA Editing by ADAR Deaminases. Annu. Rev. Biochem. 2010, 79, 321-349. [CrossRef]

87. Bass, B.L. RNA Editing by Adenosine Deaminases That Act on RNA. Annu. Rev. Biochem. 2002, 71, 817-846. [CrossRef]

88. Cao, Y.; Cao, R.; Huang, Y.; Zhou, H.; Liu, Y.; Li, X.; Zhong, W.; Hao, P. A comprehensive study on cellular RNA editing activity in response to infections with different subtypes of influenza a viruses. BMC Genom. 2018, 19, 925. [CrossRef]

89. Pauli, E.-K.; Schmolke, M.; Hofmann, H.; Ehrhardt, C.; Flory, E.; Münk, C.; Ludwig, S. High level expression of the anti-retroviral protein APOBEC3G is induced by influenza A virus but does not confer antiviral activity. Retrovirology 2009, 6, 38. [CrossRef] [PubMed]

90. Chemudupati, M.; Kenney, A.D.; Bonifati, S.; Zani, A.; McMichael, T.M.; Wu, L.; Yount, J.S. From APOBEC to ZAP: Diverse mechanisms used by cellular restriction factors to inhibit virus infections. Biochim. Biophys. Acta (BBA) Mol. Cell Res. 2019, 1866, 382-394. [CrossRef] [PubMed]

91. Tang, Q.; Wang, X.; Gao, G.; Lyles, D.S. The Short Form of the Zinc Finger Antiviral Protein Inhibits Influenza A Virus Protein Expression and Is Antagonized by the Virus-Encoded NS1. J. Virol. 2017, 91, e01909-e01916. [CrossRef]

92. Liu, C.-H.; Zhou, L.; Chen, G.; Krug, R.M. Battle between influenza A virus and a newly identified antiviral activity of the PARP-containing ZAPL protein. Proc. Natl. Acad. Sci. USA 2015, 112, 14048-14053. [CrossRef]

93. Luo, X.; Wang, X.; Gao, Y.; Zhu, J.; Liu, S.; Gao, G.; Gao, P. Molecular Mechanism of RNA Recognition by Zinc-Finger Antiviral Protein. Cell Rep. 2020, 30, 46-52. [CrossRef] [PubMed]

94. Meagher, J.L.; Takata, M.; Gonçalves-Carneiro, D.; Keane, S.C.; Rebendenne, A.; Ong, H.; Orr, V.K.; MacDonald, M.R.; Stuckey, J.A.; Bieniasz, P.D.; et al. Structure of the zinc-finger antiviral protein in complex with RNA reveals a mechanism for selective targeting of CG-rich viral sequences. Proc. Natl. Acad. Sci. USA 2019, 116, 24303-24309. [CrossRef]

95. McKellar, J.; Rebendenne, A.; Wencker, M.; Moncorgé, O.; Goujon, C. Mammalian and Avian Host Cell Influenza A Restriction Factors. Viruses 2021, 13, 522. [CrossRef] 
96. Martin-Sancho, L.; Tripathi, S.; Rodriguez-Frandsen, A.; Pache, L.; Sanchez-Aparicio, M.; McGregor, M.J.; Haas, K.M.; Swaney, D.L.; Nguyen, T.T.; Mamede, J.I.; et al. Restriction factor compendium for influenza A virus reveals a mechanism for evasion of autophagy. Nat. Microbiol. 2021, 6, 1319-1333. [CrossRef]

97. Staller, E.; Sheppard, C.M.; Baillon, L.; Frise, R.; Peacock, T.P.; Sancho-Shimizu, V.; Barclay, W.S. A natural variant in ANP32B impairs influenza virus replication in human cells. J. Gen. Virol. 2021, 102. [CrossRef] [PubMed]

98. Opgenorth, P.; Costello, Z.; Okada, T.; Goyal, G.; Chen, Y.; Gin, J.; Benites, V.; de Raad, M.; Northen, T.R.; Deng, K.; et al. Lessons from Two Design-Build-Test-Learn Cycles of Dodecanol Production in Escherichia coli Aided by Machine Learning. ACS Synth. Biol. 2019, 8, 1337-1351. [CrossRef]

99. Lawson, C.E.; Harcombe, W.R.; Hatzenpichler, R.; Lindemann, S.R.; Löffler, F.E.; O’Malley, M.A.; García Martín, H.; Pfleger, B.F.; Raskin, L.; Venturelli, O.S.; et al. Common principles and best practices for engineering microbiomes. Nat. Rev. Microbiol. 2019, 17, 725-741. [CrossRef] [PubMed]

100. Gan, S.K.-E.; Phua, S.-X.; Yeo, J.Y. Sagacious Epitope Selection for Vaccines, and Both Antibody-Based Therapeutics and Diagnostics: Tips From Virology and Oncology. Preprints 2021. [CrossRef]

101. Goris, T.; Pérez-Valero, Á.; Martínez, I.; Yi, D.; Fernández-Calleja, L.; San León, D.; Bornscheuer, U.T.; Magadán-Corpas, P.; Lombó, F.; Nogales, J. Repositioning microbial biotechnology against COVID-19: The case of microbial production of flavonoids. Microb. Biotechnol. 2021, 14, 94-110. [CrossRef] [PubMed]

102. Kitney, R.I.; Bell, J.; Philp, J. Build a Sustainable Vaccines Industry with Synthetic Biology. Trends Biotechnol. 2021, 39, 866-874. [CrossRef]

103. World Health Organization. Human Infection with Avian Influenza A(H10N3)-China. Available online: https://www.who.int/ emergencies/disease-outbreak-news/item/human-infection-with-avian-influenza-a(h10n3)-china (accessed on 13 June 2021).

104. Wang, Y.; Niu, S.; Zhang, B.; Yang, C.; Zhou, Z. The whole genome analysis for the first human infection with H10N3 influenza virus in China. J. Infect. 2021. [CrossRef] [PubMed]

105. Si, L.; Bai, H.; Oh, C.Y.; Jin, L.; Prantil-Baun, R.; Ingber, D.E.; Mostafa, H.H. Clinically Relevant Influenza Virus Evolution Reconstituted in a Human Lung Airway-on-a-Chip. Microbiol. Spectr. 2021, 9, e00257-21. [CrossRef]

106. Cao, Y.; Liu, H.; Yan, Y.; Liu, W.; Liu, D.; Li, J. Discriminating Clonotypes of Influenza A Virus Genes by Nanopore Sequencing. Int. J. Mol. Sci. 2021, 22, 10069. [CrossRef]

107. Domingo, E.; Sheldon, J.; Perales, C. Viral Quasispecies Evolution. Microbiol. Mol. Biol. Rev. 2012, 76, 159-216. [CrossRef]

108. Coombs, K.M.; Berard, A.; Xu, W.; Krokhin, O.; Meng, X.; Cortens, J.P.; Kobasa, D.; Wilkins, J.; Brown, E.G. Quantitative Proteomic Analyses of Influenza Virus-Infected Cultured Human Lung Cells. J. Virol. 2010, 84, 10888-10906. [CrossRef] [PubMed]

109. Bradel-Tretheway, B.G.; Mattiacio, J.L.; Krasnoselsky, A.; Stevenson, C.; Purdy, D.; Dewhurst, S.; Katze, M.G. Comprehensive Proteomic Analysis of Influenza Virus Polymerase Complex Reveals a Novel Association with Mitochondrial Proteins and RNA Polymerase Accessory Factors. J. Virol. 2011, 85, 8569-8581. [CrossRef]

110. Han, N.; Hwang, W.; Tzelepis, K.; Schmerer, P.; Yankova, E.; MacMahon, M.; Lei, W.M.; Katritsis, N.; Liu, A.; Felgenhauer, U.; et al. Identification of SARS-CoV-2-induced pathways reveals drug repurposing strategies. Sci. Adv. 2021, 7, eabh3032. [CrossRef]

111. Kaufmann, S.H.E.; Dorhoi, A.; Hotchkiss, R.S.; Bartenschlager, R. Host-directed therapies for bacterial and viral infections. Nat. Rev. Drug Discov. 2018, 17, 35-56. [CrossRef]

112. Keshavarz, M.; Solaymani-Mohammadi, F.; Namdari, H.; Arjeini, Y.; Mousavi, M.J.; Rezaei, F. Metabolic host response and therapeutic approaches to influenza infection. Cell. Mol. Biol. Lett. 2020, 25, 15. [CrossRef] [PubMed]

113. Gaur, P.; Munjhal, A.; Lal, S.K. Influenza virus and cell signaling pathways. Med. Sci. Monit. 2011, 17, RA148-RA154. [CrossRef] [PubMed]

114. Influenza Research Database. Available online: https:/ /www.fludb.org/brc/home.spg?decorator=influenza (accessed on 15 September 2021).

115. Influenza Virus Resource. Influenza Virus Database. Available online: https://www.ncbi.nlm.nih.gov/genomes/FLU/Database/ nph-select.cgi?go=database (accessed on 15 September 2021).

116. Influenza Research Database. Identify Point Mutations in Proteins. Available online: https://www.fludb.org/brc/mutation.spg? method=ShowCleanInputPage\&decorator=influenza (accessed on 15 September 2021).

117. Virus Pathogen Resource. Virus Pathogen Database and Analysis Resource (ViPR). Available online: https://www.viprbrc.org/ brc/home.spg?decorator=vipr (accessed on 15 September 2021).

118. Liechti, R.; Gleizes, A.; Kuznetsov, D.; Bougueleret, L.; Le Mercier, P.; Bairoch, A.; Xenarios, I. OpenFluDB, a database for human and animal influenza virus. Database 2010, 2010. [CrossRef]

119. Yin, R.; Tran, V.H.; Zhou, X.; Zheng, J.; Kwoh, C.K. Predicting antigenic variants of H1N1 influenza virus based on epidemics and pandemics using a stacking model. PLoS ONE 2018, 13, e0207777. [CrossRef]

120. Huddleston, J.; Barnes, J.R.; Rowe, T.; Xu, X.; Kondor, R.; Wentworth, D.E.; Whittaker, L.; Ermetal, B.; Daniels, R.S.; McCauley, J.W.; et al. Integrating genotypes and phenotypes improves long-term forecasts of seasonal influenza A/H3N2 evolution. ELife 2020, 9, e60067. [CrossRef] [PubMed]

121. Yin, R.; Luusua, E.; Dabrowski, J.; Zhang, Y.; Kwoh, C.K. Tempel: Time-series mutation prediction of influenza A viruses via attention-based recurrent neural networks. Bioinformatics 2020, 36, 2697-2704. [CrossRef]

122. Makau, J.N.; Watanabe, K.; Ishikawa, T.; Mizuta, S.; Hamada, T.; Kobayashi, N.; Nishida, N. Identification of small molecule inhibitors for influenza a virus using in silico and in vitro approaches. PLoS ONE 2017, 12, e0173582. [CrossRef] 
123. Yao, Y.; Kadam, R.U.; Lee, C.-C.D.; Woehl, J.L.; Wu, N.C.; Zhu, X.; Kitamura, S.; Wilson, I.A.; Wolan, D.W. An influenza A hemagglutinin small-molecule fusion inhibitor identified by a new high-throughput fluorescence polarization screen. Proc. Natl. Acad. Sci. USA 2020, 117, 18431-18438. [CrossRef]

124. Dongen, M.J.P.v.; Kadam, R.U.; Juraszek, J.; Lawson, E.; Brandenburg, B.; Schmitz, F.; Schepens, W.B.G.; Stoops, B.; Diepen, H.A.v.; Jongeneelen, M.; et al. A small-molecule fusion inhibitor of influenza virus is orally active in mice. Science 2019, 363, eaar6221. [CrossRef]

125. Corona, A. A Universal Influenza Vaccine: How Close Are We? Available online: https://asm.org/Articles/2019/August/AUniversal-Influenza-Vaccine-How-Close-Are-We (accessed on 27 June 2021).

126. Byrn, R.A.; Jones, S.M.; Bennett, H.B.; Bral, C.; Clark, M.P.; Jacobs, M.D.; Kwong, A.D.; Ledeboer, M.W.; Leeman, J.R.; McNeil, C.F.; et al. Preclinical Activity of VX-787, a First-in-Class, Orally Bioavailable Inhibitor of the Influenza Virus Polymerase PB2 Subunit. Antimicrob. Agents Chemother. 2015, 59, 1569-1582. [CrossRef]

127. Soh, Y.Q.S.; Malone, K.D.; Eguia, R.T.; Bloom, J.D. Comprehensive Profiling of Mutations to Influenza Virus PB2 That Confer Resistance to the Cap-Binding Inhibitor Pimodivir. Viruses 2021, 13, 1196. [CrossRef]

128. Galindez, G.; Matschinske, J.; Rose, T.D.; Sadegh, S.; Salgado-Albarrán, M.; Späth, J.; Baumbach, J.; Pauling, J.K. Lessons from the COVID-19 pandemic for advancing computational drug repurposing strategies. Nat. Comput. Sci. 2021, 1, 33-41. [CrossRef]

129. Jin, W.; Stokes, J.M.; Eastman, R.T.; Itkin, Z.; Zakharov, A.V.; Collins, J.J.; Jaakkola, T.S.; Barzilay, R. Deep learning identifies synergistic drug combinations for treating COVID-19. Proc. Natl. Acad. Sci. USA 2021, 118, e2105070118. [CrossRef]

130. Ling, W.-L.; Lua, W.-H.; Gan, S.K.-E. Sagacity in antibody humanization for therapeutics, diagnostics and research purposes: Considerations of antibody elements and their roles. Antib. Ther. 2020, 3, 71-79. [CrossRef] [PubMed]

131. Ling, W.-L.; Su, C.T.-T.; Lua, W.-H.; Yeo, J.Y.; Poh, J.-J.; Ng, Y.-L.; Wipat, A.; Gan, S.K.-E. Engaging the 'A' Class Antibody: Variable-Heavy $(\mathrm{VH})$ region influencing IgA1\&2 engagement of Fc $\alpha$ RI and superantigen proteins G, A, and L. bioRxiv 2021. [CrossRef]

132. Su, C.T.-T.; Lua, W.-H.; Poh, J.-J.; Ling, W.-L.; Yeo, J.Y.; Gan, S.K.-E. Molecular Insights of Nickel Binding to Therapeutic Antibodies as a Possible New Antibody Superantigen. Front. Immunol. 2021, 12. [CrossRef] [PubMed]

133. Lua, W.-H.; Su, C.T.-T.; Yeo, J.Y.; Poh, J.-J.; Ling, W.-L.; Phua, S.-X.; Gan, S.K.-E. Role of the IgE variable heavy chain in FceRI $\alpha$ and superantigen binding in allergy and immunotherapy. J. Allergy Clin. Immunol. 2019, 144, 514-523. [CrossRef] [PubMed]

134. Deacy, A.M.; Gan, S.K.-E.; Derrick, J.P. Superantigen Recognition and Interactions: Functions, Mechanisms and Applications. Front. Immunol. 2021, 12. [CrossRef]

135. Cheng, M.H.; Zhang, S.; Porritt, R.A.; Noval Rivas, M.; Paschold, L.; Willscher, E.; Binder, M.; Arditi, M.; Bahar, I. Superantigenic character of an insert unique to SARS-CoV-2 spike supported by skewed TCR repertoire in patients with hyperinflammation. Proc. Natl. Acad. Sci. USA 2020, 117, 25254-25262. [CrossRef]

136. ClinicalTrials.gov. First-in-Human Clinical Trial of a Mosaic Quadrivalent Influenza Vaccine Compared with a Licensed Inactivated Seasonal QIV, in Healthy Adults. Available online: https:/ / clinicaltrials.gov / ct2/show / NCT04896086 (accessed on 27 June 2021).

137. Boyoglu-Barnum, S.; Ellis, D.; Gillespie, R.A.; Hutchinson, G.B.; Park, Y.-J.; Moin, S.M.; Acton, O.J.; Ravichandran, R.; Murphy, M.; Pettie, D.; et al. Quadrivalent influenza nanoparticle vaccines induce broad protection. Nature 2021, 592, 623-628. [CrossRef]

138. Bull, J.J.; Sanjuán, R.; Wilke, C.O. Theory of Lethal Mutagenesis for Viruses. J. Virol. 2007, 81, 2930-2939. [CrossRef]

139. Geraghty, R.J.; Aliota, M.T.; Bonnac, L.F. Broad-Spectrum Antiviral Strategies and Nucleoside Analogues. Viruses 2021, $13,667$. [CrossRef]

140. Summers, J.; Litwin, S. Examining The Theory of Error Catastrophe. J. Virol. 2006, 80, 20-26. [CrossRef]

141. Pauly, M.D.; Lauring, A.S.; Dermody, T.S. Effective Lethal Mutagenesis of Influenza Virus by Three Nucleoside Analogs. J. Virol. 2015, 89, 3584-3597. [CrossRef]

142. Wyss Institute. Broad-Spectrum RNA Therapeutic for COVID-19 and Influenza. Available online: https://wyss.harvard.edu/ technology/broad-spectrum-rna-therapeutic-for-covid-19-and-influenza-3/ (accessed on 4 August 2021).

143. Pérez-Losada, M.; Arenas, M.; Galán, J.C.; Palero, F.; González-Candelas, F. Recombination in viruses: Mechanisms, methods of study, and evolutionary consequences. Infect. Genet. Evol. 2015, 30, 296-307. [CrossRef]

144. Galetto, R.; Negroni, M. Mechanistic features of recombination in HIV. AIDS Rev. 2005, 7, 92-102. [PubMed]

145. Burke, D.S. Recombination in HIV: An Important Viral Evolutionary Strategy. Emerg. Infect. Dis. J. 1997, 3, 253. [CrossRef] [PubMed]

146. Tan, Y.; Hassan, F.; Schuster, J.E.; Simenauer, A.; Selvarangan, R.; Halpin, R.A.; Lin, X.; Fedorova, N.; Stockwell, T.B.; Lam, T.T.-Y.; et al. Molecular Evolution and Intraclade Recombination of Enterovirus D68 during the 2014 Outbreak in the United States. J. Virol. 2016, 90, 1997-2007. [CrossRef] [PubMed] 